\title{
Fusarium spp., Cylindrocarpon spp., and Environmental Stress in the Etiology of a Canker Disease of Cold-Stored Fruit and Nut Tree Seedlings in California
}

Stephen M. Marek, Department of Entomology and Plant Pathology, Oklahoma State University, Stillwater 74078-3033; and Mohammad A. Yaghmour and Richard M. Bostock, Department of Plant Pathology, University of California, Davis 95616

\begin{abstract}
Marek, S. M., Yaghmour, M. A., and Bostock, R. M. 2013. Fusarium spp., Cylindrocarpon spp., and environmental stress in the etiology of a canker disease of cold-stored fruit and nut tree seedlings in California. Plant Dis. 97:259-270.

The principal objective of this study was to determine the etiology of a canker disease in dormant stone fruit and apple tree seedlings maintained in refrigerated storage that has significantly impacted California fruit and nut tree nurseries. Signs and symptoms of the disease develop during storage or soon after planting, with subsequent decline and death of young trees. Isolations from both diseased and healthy almond and apple trees and Koch's postulates using stem segments of desiccation-stressed almond trees as hosts implicated Fusarium avenaceum and $F$. acuminatum as the primary causal agents. F. solani, Ilyonectria robusta, and Cylindrocarpon obtusiusculum were also capable of causing similar symptoms but were less frequently encountered in isola-

tions of diseased tissue. Loss of bark turgidity in excised almond stem segments, as can occur in cold-stored seedlings, correlated with increased susceptibility to $F$. acuminatum, with maximum canker development occurring after relative bark turgidity dropped below a threshold of approximately $86 \%$. Healthy almond trees, almond scion budwood, and a wheat cover crop used in fields where tree seedlings were grown and maintained until cold storage all possessed asymptomatic infections of F. acuminatum, F. avenaceum, and C. obtusiusculum as determined by activation following overnight freezing, cold storage, or desiccation.
\end{abstract}

In the winter of 1997-98, a severe canker disease affecting almond trees and other fruit tree species appeared during cold storage of the dormant trees in several major nurseries in California. The predominant symptom was necrosis of the inner bark, cambium, and sapwood which, when severe, was capable of girdling the tree. In moist conditions, symptoms were often associated with white, pink, and orange fungal sporulation on the surface of the bark, emerging through lenticels, directly over or adjacent to necroses (Fig. 1). Symptoms often occurred at the graft union, with most necrotic areas occurring on the scion but sometimes also spreading to the rootstock. In the absence of external signs, internal necroses were not readily evident in many trees whose bark was dark brown; however, lesions were detectable on tissues possessing light-brown or green bark. The difficulty in identifying infected trees led to the inadvertent transfer of affected trees to growers, resulting in further disease development and death of newly planted trees in the field. From 1998 to 2001, the disease persisted and recurred sporadically in several nurseries, resulting in estimated losses of many millions of dollars, which included loss of some newly planted orchards. Contributing to disease development based on observation and empirical evidence were abiotic stresses, notably desiccation of the trees following removal from the field and prior to cold storage, and temperature variation in the refrigerated warehouses during cold storage where, in some areas, low temperatures permitted ice formation on the trees. During the past decade, the disease has been rare or not observed in nurseries. However, in 2010 and 2011, the disease reemerged in one of the original nurseries, resulting in significant losses. With the recent

Corresponding author: R. M. Bostock, E-mail: rmbostock@ucdavis.edu

* The $\boldsymbol{e}$-Xtra logo stands for "electronic extra" and indicates that a supplementary figure and a supplementary table are available online, and that Figures 1 through 6 are in color online.

Accepted for publication 4 September 2012.

http://dx.doi.org/10.1094/PDIS-04-12-0355-RE

(C) 2013 The American Phytopathological Society outbreak, rainfall during the period of lifting of tree seedlings in the field was unusually high, similar to the weather conditions prevalent during the earlier outbreak.

Nurseries in California supply many species and varieties of fruit and nut trees to growers throughout the state and region. A common practice of growing these trees begins when rootstock seed or vegetative cuttings are planted in the fall into fumigated, prepared beds and germinate or root in winter with the seasonal rains. In the spring (April to June), rootstock saplings are grafted with the desired scion bud from the nursery's mother trees. After the buds begin to grow, the trees are trained and staked and rootstock suckers are trimmed back. In the autumn (November), trees are either allowed to defoliate naturally or sprayed with a defoliant. In the late fall and early winter when trees have become dormant, they are undercut and dug from nursery beds. Trees are graded and either stored outside with their roots heeled in sawdust beds or placed into cold storage in large refrigerated warehouses. Both methods permit nurseries to expedite packing and shipping of trees to growers for spring planting. Cold storage can reduce time and labor cost, compared with heeling in sawdust beds, and provides greater control over temperature and humidity to maintain trees in a dormant state.

The objectives of this study were to identify the causal agent or agents of the cold-storage canker disease, assess the role of desiccation as a predisposing factor in disease development, examine asymptomatic trees and other potential inoculum sources for the presence of these pathogens, and review nursery practices in relation to disease etiology.

\section{Materials and Methods}

Isolation and culture of fungal isolates. To assess the microbial flora associated with symptomatic seedlings and potential sources of inoculum, samples were obtained directly from four nurseries and five growers' fields. The nine locations were anonymously assigned numbers (1 to 9), which will be used when referring to specific locations herein. Specimens were examined for the characteristic external signs (white, pink, and orange sporulation) and internal symptoms (necrosis of the inner bark and cambium) of the disease. Fungal and bacterial isolations were made from sections of bark and cambium (5 to $10 \mathrm{~cm}^{2}$ ) excised from diseased and 

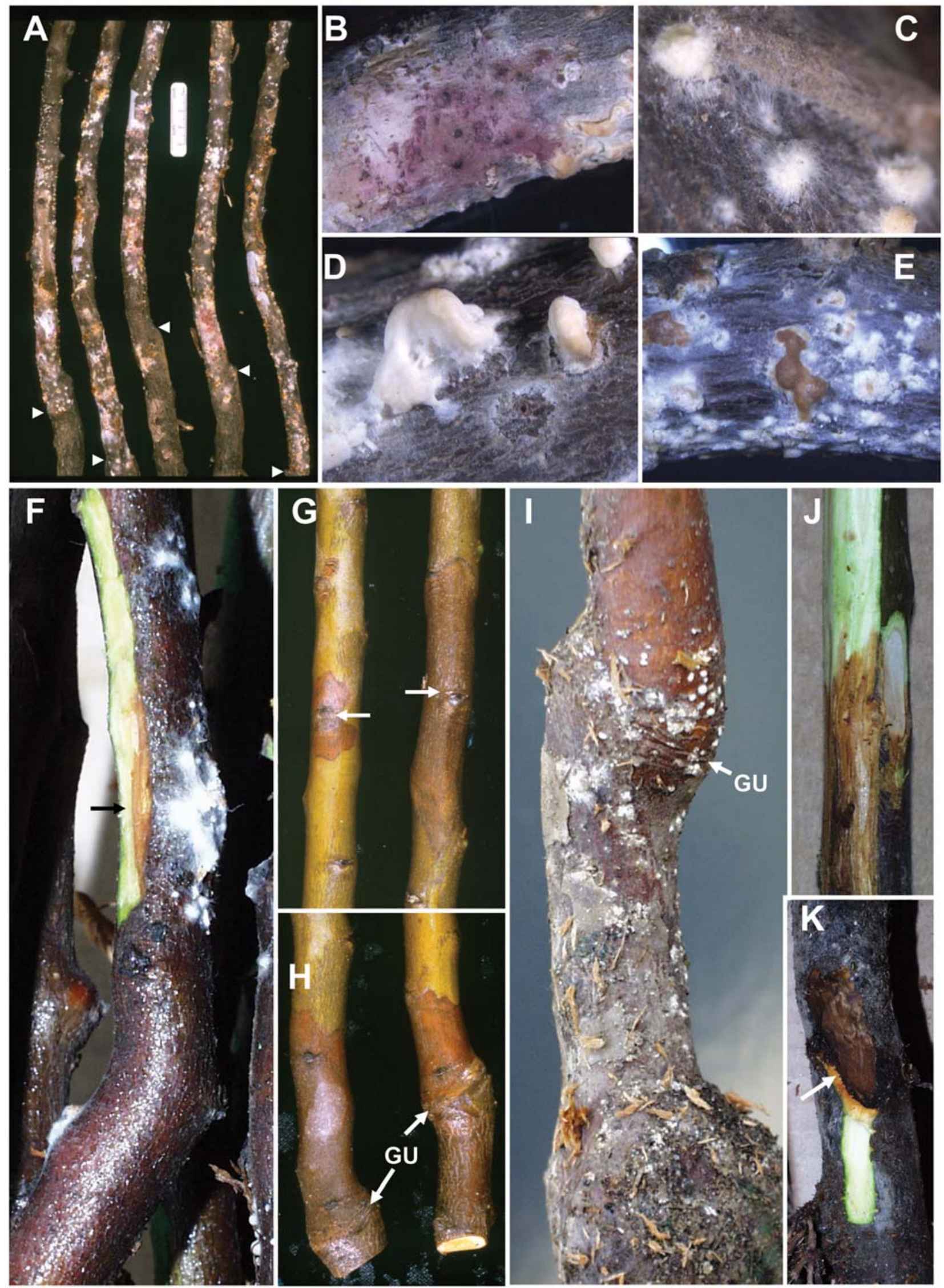

Fig. 1. Symptoms and signs of cold storage canker on almond and apple trees. Almond trees are from A-F, location 1 and $\mathbf{G}$ and $\mathbf{H}$, location 9 and apple trees are from $\mathbf{I - K}$, location 3. Most symptoms and signs were localized around the graft union ("GU", arrowheads A, arrows in $\mathrm{H}$ and I). However, some lesions appeared to start around the nodes of the scion (arrows, G). Punctate sporulation appeared to emerge through the lenticels over colonized necrotic tissues ( $F$ and $I)$. In advanced stages, sporulation coalesced into beige, brown, or maroon sporodochia-like structures (B-F). Necrosis of the inner bark, cambium, and sapwood primarily occurred on the scion (arrows, $\mathrm{F}-\mathrm{H}$, J) but occasionally spread to the rootstock (arrow, K). 
apparently healthy tissues. Tissue pieces were surface sterilized (15 min in $1 \% \mathrm{NaOCl}+10 \%$ ethanol followed by two washes in sterile deionized water) and placed on selective (Nash-Snyder or DCPA [51] and potato dextrose agar [PDA] + tetracycline at $100 \mathrm{ppm}$ ) and nonselective (water agar) media. Water-soaked lesions were plated onto PARP (31) and King's B (32) media to test for the presence of Phytophthora and Pythium spp. or Pseudomonas syringae, respectively. To isolate from sawdust bedding, three 10-g subsamples were dilution plated in triplicate and isolates subcultured from $10^{-3}, 10^{-4}$, and $10^{-5}$ dilution plates. Fungal isolates were hyphal tipped and grown for 7 to 30 days on media promoting sporulation (e.g., potato-carrot agar, carnation leaf agar [CLA], Spezieller Nährstoffärmer agar [SNA], and SNA $+0.1 \%$ yeast extract [SNAY]) or other taxonomically important structures (e.g., chlamydospores on soil agar) (33) and identified according to published keys $(14,25,41)$ or described.

Isolates were stored on filter paper at $4^{\circ} \mathrm{C}$. To generate filter paper cultures, sterile filter paper discs (e.g., Whatman 1 or equivalent) were laid onto the surface of PDA plates and inoculated in the center. After fungal isolates had completely colonized the filter (3 to 10 days), the paper was peeled from the plate, placed in a sterile petri plate in a laminar flow hood, and allowed to air-dry for 2 to 7 days. Dried filters were then cut into 4- to $6-\mathrm{cm}^{2}$ pieces and stored in sterile vials at $4^{\circ} \mathrm{C}$. Colonized filter paper pieces also were used as inoculum for pathogenicity tests. The fungal isolates from 2010-11 were stored in $25 \%$ glycerol in potato dextrose broth at $-80^{\circ} \mathrm{C}$.

Bacterial isolates were streak-purified on nutrient agar or King's $\mathrm{B}$, and single colonies used to grow up overnight Luria-Bertani cultures, brought to $15 \%$ glycerol, and stored at $-80^{\circ} \mathrm{C}$.

Micrographs of fungal structures were captured with a DKC5000 CatsEye CCD digital camera (Sony Electronics, Inc.) mounted on a Nikon Microphot-SA using Nomarski differential interference contrast optics, and the images were processed using Adobe Photoshop (Adobe Systems Inc.).

Disease assays. To evaluate the potential of fungal isolates collected from nursery samples to cause disease, a preliminary test was performed using almond (Prunus dulcis (Mill.) Webb 'Carmel') branches ( 1 to $2 \mathrm{~cm}$ in diameter) harvested from mature trees growing at the Armstrong Research Farm at the University of California (UC) Davis. Branches were trimmed of leaves, cut to 50- to 60-cm segments, surface sterilized, and inoculated with agar plugs from growing cultures placed either directly onto intact bark or over a stab wound made with a dissecting needle. A sterile agar plug was placed over a stab wound as a control. Inoculated stem segments were incubated in closed plastic bags at 5 to $10^{\circ} \mathrm{C}$ for 52 days with moist paper towels. Bark then was removed from test points and lesion lengths and widths were measured.

To compare pathogenicity of species and assess the effect of environment on canker development, disease assays were conducted with smaller stem sections ( 1 to $2 \mathrm{~cm}$ in diameter by approximately $10 \mathrm{~cm}$ ) using surface-sterilized dormant almond ('Padre') branches. This method involved making two stab wounds with a standard dissecting needle at about $4 \mathrm{~cm}$ apart through the outer bark, about 1 to $2 \mathrm{~mm}$ deep. One wound was inoculated with a filter paper piece (approximately $4 \mathrm{~mm}^{2}$ ) colonized by the test fungus and was affixed over the wound in the stem with BuddyTape (Riken USA Corp.). The other stab wound was also covered with Buddy-Tape and used as a wound, noninoculated control. The inoculated stem segments were then placed in sterile test tubes (25 by $200 \mathrm{~mm}$ ) fitted with foam plugs and incubated at ambient relative humidity (10 to $35 \%$ ). The inoculated branches were incubated at $15^{\circ} \mathrm{C}$ for 14 days. At the end of the incubation, bark was removed to reveal lesions, and lesion lengths and widths were measured. Stem segments inoculated with isolates of the pathogenic fungi Monilinia fructicola (G. Winter) Honey (isolate MUK-1) and M. laxa (Aderh. \& Ruhland) Honey were included with each assay as positive controls. To fulfill Koch's last postulate of reisolation of the inoculated pathogen, sapwood lesions (without bark or inoculum paper) greater in size than control stab wounds were plated onto the selective medium originally used for that isolate. Tissue from the control wounds was also plated onto the medium.

DNA extraction, PCR amplification for direct sequencing, and DNA sequencing conditions. To complement the morphology-based classification of the fungal isolates that were found to satisfy Koch's postulates, a DNA sequence-based method was used to confirm species identities. Mycelia were scraped from a culture growing on a PDA plate and used for DNA extraction with the FastDNA Kit in conjunction with the FastPrep Instrument (MP Biomedicals). Buffer CLS-Y was used, and grinding intensity was set to 4.5 for $30 \mathrm{~s}$. For Fusarium spp., a partial region of the translation elongation factor $1-\alpha$ gene $(E F 1-\alpha)$ was targeted for amplification. Primers ef 1 and ef 2 were used for amplification (24). PCRs were performed using GoTaq Colorless Master Mix (Promega Corp.) in a $25-\mu l$ reaction volume according to the manufacturer's instructions. The PCR program consisted of a 3-min initial denaturation step at $94^{\circ} \mathrm{C} ; 35$ cycles of $10 \mathrm{~s}$ at $94^{\circ} \mathrm{C}, 20 \mathrm{~s}$ at the primer-pair-dependent annealing temperature, and $1 \mathrm{~min}$ at $72^{\circ} \mathrm{C}$; followed by a final extension of $7 \mathrm{~min}$ at $72^{\circ} \mathrm{C}$. Amplified PCR products were resolved in $0.8 \%$ agarose gels. PCR products were purified by sodium acetate precipitation (47). For Cylindrocarpon isolates collected during the initial outbreak in 1997-98, the nuclear ribosomal (nr)DNA internal transcribed spacer (ITS) region was targeted for amplification using ITS4 and ITS5 primers (55). For Ilyonectria robusta, a partial region of the $\beta$-tubulin gene $(\beta-T U B)$ was targeted for amplification. Primers T1 and T2 were used to amplify this partial region (44). DNA sequences were determined using the same primers used to amplify the partial regions of $E F 1-\alpha, I T S$, and $\beta-T U B$. Sequencing was performed at the UC Davis DNA Sequencing Facility, using ABI BigDye Terminator v3.1 Cycle Sequencing chemistry on an ABI 3730 Capillary Electrophoresis Genetic Analyzer (Applied Biosystems). Sequences of both directions were assembled with Sequencher software (v.4.10.1; Gene Codes Corporation) and compared with GenBank sequences using BLAST.

Relative bark turgidity and susceptibility to Fusarium acuminatum. To determine more precisely the relationship between bark moisture status and canker size, almond stem segments subjected to different drying periods were inoculated with Fusarium acuminatum. Relative bark turgidity was determined according to the general method of Bier (5). After the desired drying period had passed, all bark was removed from an almond stem segment and the bark (approximately1 g) immediately weighed to determine fresh weight $(\mathrm{FW})$. To prevent dehydration during bark removal, bark pieces from each stem were sealed in a 50-ml Falcon tube until the bulked pieces could be weighed. After the FWs were recorded, the bark samples were returned to the 50-ml Falcon tubes, submerged in sterile distilled water, and placed in the dark at $4{ }^{\circ} \mathrm{C}$ overnight (approximately $16 \mathrm{~h}$ ). Saturated bark samples were removed from the water, excess water blotted onto a paper towel, and the wet weight (WW) immediately determined. Bark samples were then oven dried at $80^{\circ} \mathrm{C}$ overnight, after which the dry weight (DW) was measured. Relative bark turgidity was then determined according to the following formula: $([\mathrm{FW}-\mathrm{DW}] /[\mathrm{WW}-\mathrm{DW}]) \times$ $100 \%$ (i.e., [weight of water in fresh sample/weight of water in saturated sample] $\times 100 \%$ ).

The effect of bark turgidity on susceptibility to $F$. acuminatum was determined using surface-sterilized, 10-cm-long almond (Padre) stem segments. In all, 40 stem segments were left noninoculated, placed in foam-plugged tubes, and incubated at $15^{\circ} \mathrm{C}$ at ambient humidity as above. Four random stem segments were collected and their relative bark turgidity measured after "drying periods" of $0,1,2,3,4,6,8,10,12$, and 14 days. Another 40 stem segments were inoculated with $F$. acuminatum according to the disease assay described above. After drying periods of $0,1,2,3$, $4,6,8,10,12$, and 14 days, $5 \mathrm{ml}$ of sterile distilled water was added to each of four randomly selected tubes to stop desiccation. After 14 days, the resulting lesions were photographed and measured. The Pearson product-moment correlation coefficient between lesion length and bark turgidity was determined using 
the CORREL statistical function within Microsoft Excel (Microsoft, Inc.).

Sources of inoculum. To determine potential sources of primary inoculum, stems (scion and rootstock) and roots of dormant, coldstored trees, scion budwood used for grafting at the nursery, and rootstock seed (P. persica L. (Batsch) 'Lovell') and seedlings from location 1 were examined for latent infections. Two fallow nursery fields cover-cropped in wheat (Triticum aestivum L. 'Express') and one field of peach (Lovell) rootstock seedlings were sampled in April 2000. Wheat seed used to plant fallow nursery fields also were sampled.

To detect latent endophytic infections, healthy-appearing stems were surface sterilized as in the above pathogenicity tests, frozen overnight at $-20^{\circ} \mathrm{C}$, then placed at room temperature in a moist chamber to promote sporulation. This technique permits detection of quiescent infections (37). Surface-sterilized tree stems also were allowed to desiccate for 14 to 30 days at ambient humidity until sporulation was observed.

To determine whether soilborne inoculum could systemically infect rootstock seedlings, stratified rootstock seed (30 days in moist vermiculite at $4^{\circ} \mathrm{C}$ ) were germinated in sterile soil (Yolo loam) artificially infested with $F$. acuminatum and a Cylindrocarpon sp. using barley chaff inoculum (35). After 6 months of growth, seedlings were harvested and various tissues representatively sampled. Roots, cleaned of soil, and stem sections at several distances from ground level were surface sterilized and plated on selective media. Hyphal tips were transferred to SNAY and CLA $+0.6 \% \mathrm{KCl}$ media and the resulting isolates were morphologically identified using published keys $(25,41)$.

\section{Results}

Occurrence of fungi isolated from sampling sites. During the period from summer 1998 to winter 2001, many disease samples (Fig. 1) were received from the four nurseries (locations 1 to 3, and 9) and five growers' fields (locations 4 to 8 ). Numerous fungi were isolated from the diseased trees of all locations, with additional fungi isolated from the sawdust bedding and cereal cover crops of several nurseries (Table 1). More isolates originated from nurseries than growers' fields due to the additional substrates (e.g., sawdust bedding) sampled and the repeated samplings with larger numbers of diseased specimens.

Morphological characteristics of pathogenic isolates. Of all the genera of fungi isolated, only Fusarium, the most frequently encountered genus, was isolated from every disease specimen (Table 1). Initially isolated Fusarium spp. were not keyed to species until disease assays had established isolates capable of reproducing disease symptoms. Cultural characteristics and macroconidia were used to identify $F$. avenaceum and $F$. acuminatum (Fig. 2) as the two most commonly isolated pathogenic species from diseased specimens. F. acuminatum forms chlamydospores (Fig. 2D) while

Table 1. Occurrence of fungal genera isolated from diseased trees and nursery materials

\begin{tabular}{|c|c|c|c|c|c|c|c|c|c|c|}
\hline \multirow[b]{2}{*}{ Genus, species } & \multicolumn{10}{|c|}{ Number of isolates at locations 1 through $9^{a}$} \\
\hline & 1 & 2 & 3 & 4 & 5 & 6 & 7 & 8 & 9 & Total \\
\hline \multicolumn{11}{|l|}{ Fusarium and Cylindrocarpon spp. } \\
\hline Fusarium spp. & 77 & 111 & 59 & 4 & 0 & 15 & 1 & 3 & 6 & 276 \\
\hline Fusarium avenaceum & 3 & $\ldots$ & $\ldots$ & $\ldots$ & $\ldots$ & $\ldots$ & 1 & $\ldots$ & 5 & 9 \\
\hline F. acuminatum & 6 & $\ldots$ & $\ldots$ & $\ldots$ & $\ldots$ & $\ldots$ & 2 & $\ldots$ & 12 & 20 \\
\hline F. solani & 16 & $\ldots$ & $\ldots$ & 3 & 6 & $\ldots$ & 10 & $\ldots$ & $\ldots$ & 35 \\
\hline F. equiseti (non-pathogenic in assay) & 9 & $\ldots$ & $\ldots$ & $\ldots$ & $\ldots$ & $\ldots$ & 2 & $\ldots$ & 1 & 12 \\
\hline F. oxysporum (non-pathogenic in assay) & 11 & $\ldots$ & $\ldots$ & $\ldots$ & $\ldots$ & $\ldots$ & 2 & $\ldots$ & $\ldots$ & 13 \\
\hline Cylindrocarpon obtusiusculum & 24 & $\ldots$ & $\ldots$ & $\ldots$ & $\ldots$ & $\ldots$ & $\ldots$ & $\ldots$ & $\ldots$ & 24 \\
\hline \multicolumn{11}{|l|}{ Other fungi } \\
\hline Rhizopus spp. & 3 & $\ldots$ & 8 & $\ldots$ & $\ldots$ & $\ldots$ & $\ldots$ & $\ldots$ & $\ldots$ & 11 \\
\hline Mucor and Mortierella spp. & 18 & 12 & 29 & $\ldots$ & $\ldots$ & 1 & $\ldots$ & $\ldots$ & $\ldots$ & 60 \\
\hline Syncephalastrum sp. & 1 & $\ldots$ & & $\ldots$ & $\ldots$ & $\ldots$ & $\ldots$ & $\ldots$ & $\ldots$ & 1 \\
\hline Pythium spp. & & 3 & & $\ldots$ & $\ldots$ & $\ldots$ & $\ldots$ & $\ldots$ & $\ldots$ & 3 \\
\hline Alternaria spp. and cohorts ${ }^{\mathrm{b}}$ & 149 & 14 & 29 & $\ldots$ & $\ldots$ & 5 & 8 & 2 & 16 & 223 \\
\hline Pestalotia sp. & 4 & $\ldots$ & & $\ldots$ & $\ldots$ & $\ldots$ & $\ldots$ & $\ldots$ & $\ldots$ & 4 \\
\hline Epicoccum sp. & 18 & 2 & 4 & $\ldots$ & $\ldots$ & $\ldots$ & $\ldots$ & $\ldots$ & 3 & 27 \\
\hline Nigrospora sp. & $\ldots$ & $\ldots$ & $\ldots$ & $\ldots$ & $\ldots$ & $\ldots$ & $\ldots$ & $\ldots$ & 1 & 1 \\
\hline Cladosporium sp. & 4 & 4 & 1 & $\ldots$ & $\ldots$ & $\ldots$ & $\ldots$ & $\ldots$ & 2 & 11 \\
\hline Trichoderma sp. & 3 & 6 & 14 & $\ldots$ & $\ldots$ & 1 & 2 & $\cdots$ & $\ldots$ & 26 \\
\hline Gliocladium sp. & & 4 & $\ldots$ & $\ldots$ & $\ldots$ & $\ldots$ & $\ldots$ & $\ldots$ & $\ldots$ & 4 \\
\hline Penicillium sp. & 22 & 25 & 6 & $\cdots$ & $\cdots$ & 2 & $\cdots$ & $\cdots$ & $\cdots$ & 55 \\
\hline Aspergillus spp. & 6 & 5 & 4 & $\ldots$ & $\ldots$ & $\ldots$ & $\ldots$ & $\ldots$ & $\ldots$ & 15 \\
\hline Candida and cohorts ${ }^{\mathrm{c}}$ & 8 & 11 & 3 & $\ldots$ & $\ldots$ & $\ldots$ & 2 & $\ldots$ & $\ldots$ & 24 \\
\hline Trichothecium sp. & $\ldots$ & $\ldots$ & 4 & $\ldots$ & $\ldots$ & 3 & $\ldots$ & $\ldots$ & $\ldots$ & 7 \\
\hline Gliocephalastrum sp. & 1 & $\ldots$ & $\ldots$ & $\ldots$ & $\ldots$ & $\ldots$ & $\ldots$ & $\ldots$ & $\ldots$ & 1 \\
\hline Geotrichum sp. & 1 & 1 & 4 & $\ldots$ & $\ldots$ & $\ldots$ & $\cdots$ & $\ldots$ & $\cdots$ & 6 \\
\hline Phoma spp. & 1 & 2 & 1 & $\ldots$ & $\ldots$ & $\ldots$ & $\ldots$ & 2 & 11 & 17 \\
\hline Sphaeropsis sp. & $\ldots$ & 8 & 9 & $\ldots$ & $\ldots$ & $\ldots$ & $\ldots$ & 4 & $\ldots$ & 21 \\
\hline Phomopsis sp. & & $\ldots$ & 4 & $\ldots$ & $\ldots$ & $\ldots$ & $\ldots$ & $\ldots$ & $\ldots$ & 4 \\
\hline Botrytis sp. & 12 & $\ldots$ & 2 & $\ldots$ & $\ldots$ & $\ldots$ & $\ldots$ & $\ldots$ & $\ldots$ & 14 \\
\hline Graphium and Stilbum spp. & $\ldots$ & 2 & 8 & $\ldots$ & $\ldots$ & $\ldots$ & $\ldots$ & $\ldots$ & $\ldots$ & 10 \\
\hline Chaetomium sp. & 7 & $\ldots$ & $\ldots$ & $\ldots$ & $\ldots$ & $\ldots$ & $\ldots$ & $\ldots$ & $\ldots$ & 7 \\
\hline Acremonium sp. & $\ldots$ & 5 & $\ldots$ & $\ldots$ & $\ldots$ & $\ldots$ & $\ldots$ & $\ldots$ & $\ldots$ & 5 \\
\hline Verticillium $\mathrm{spp}$. & 4 & $\ldots$ & $\ldots$ & $\ldots$ & $\ldots$ & $\ldots$ & $\ldots$ & $\ldots$ & $\ldots$ & 4 \\
\hline Heliscus lugdunensis & 1 & $\ldots$ & $\ldots$ & $\ldots$ & $\ldots$ & $\ldots$ & $\ldots$ & $\ldots$ & $\ldots$ & 1 \\
\hline Cylindrocladium sp. & 2 & $\ldots$ & $\ldots$ & $\ldots$ & $\ldots$ & $\ldots$ & $\ldots$ & $\ldots$ & $\ldots$ & 2 \\
\hline Rhizoctonia spp. and Mycelia sterilia & $\ldots$ & $\ldots$ & 5 & $\ldots$ & $\ldots$ & 1 & 3 & 16 & $\ldots$ & 25 \\
\hline Total & 411 & 215 & 194 & 7 & 6 & 28 & 33 & 27 & 57 & 978 \\
\hline
\end{tabular}

${ }^{a}$ Sampled specimens at location $1=$ cold-stored healthy and diseased almond trees and mulch bedding, rootstock seedlings, budwood, and wheat cover crops from nursery; location 2 = cold-stored diseased almond trees and mulch bedding from nursery; location $3=$ cold-stored diseased apple trees and mulch bedding from nursery; locations $4-8=$ diseased almond trees from San Joaquin County growers' fields; and location $9=$ cold-stored diseased almond trees from nursery.

b Alternaria, Ulocladium, and Stemphyllium spp.

${ }^{\mathrm{c}}$ Candida spp., Aureobasidium spp., and assorted dimorphic yeasts. 

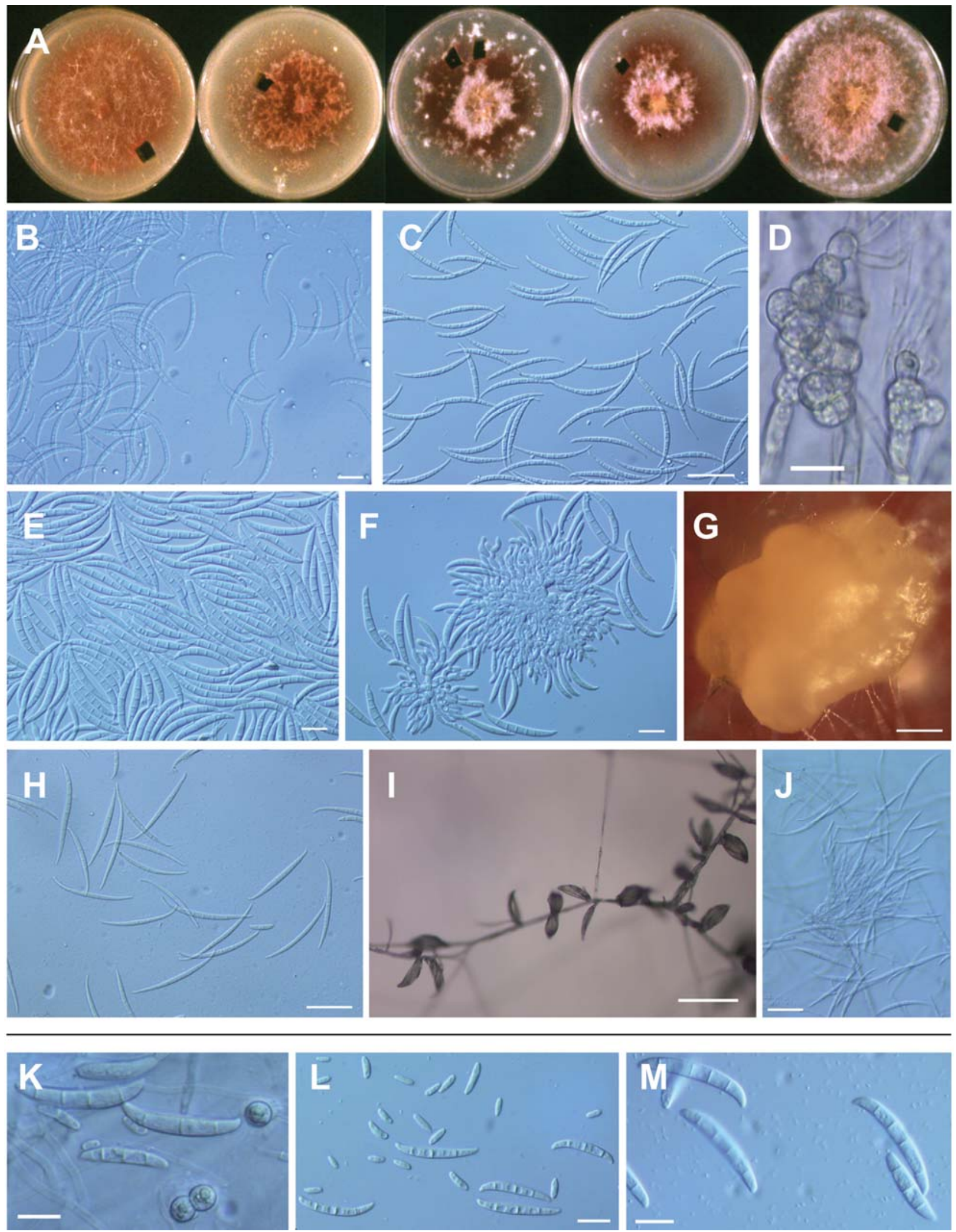

Fig. 2. Fusarium spp. causing lesions in pathogenicity tests. A, Cultures of Fusarium acuminatum and F. avenaceum grown for 21 days on Spezieller Nährstoffärmer agar + $0.1 \%$ yeast extract medium both deposited red to reddish-tan pigment in the medium, formed fluffy white to reddish tan aerial mycelia; and $\mathbf{G}$, occasionally formed slimy orange sporodochia with age. B and C, Macroconidia of $F$. acuminatum were thin and sickle-shaped with an elongated apical cell when sampled from $\mathbf{G}$, a mature sporodochium and $\mathbf{E}$, slightly thicker when sampled from $\mathbf{F}$, an immature sporodochium. $\mathbf{D}$, Formation of chlamydospores by $F$. acuminatum occurred infrequently, although more consistently on soil extract agar. $\mathrm{H}-\mathrm{J}$, Macroconidia of $F$. avenaceum were longer, thinner, and straighter than $F$. acuminatum, with an elongated apical cell that was often bent. Macroconidia of $F$. avenaceum were borne on both $\mathbf{I}$, monophialides and $\mathbf{J}$, sporodochia. Microconidia were sparse to absent in isolates of both $F$. acuminatum and F. avenaceum. K-M, F. solani isolates formed thicker, stout macroconidia with rounded apical and foot cells; $\mathbf{K}$, spherical chlamydospores alone and in pairs; and, often, $\mathrm{L}$, abundant microconidia. Cultures of $F$. solani were cream colored with a slight violet pigmentation in centers (not shown). Bars $=50 \mu \mathrm{m}(\mathrm{B}, \mathrm{C}, \mathrm{H}$, and J), $20 \mu \mathrm{m}(\mathrm{D}-\mathrm{F}$ and $\mathrm{K}-\mathrm{M}), 200 \mu \mathrm{m}(\mathrm{G})$, and $133 \mu \mathrm{m}(\mathrm{I})$. 
$F$. avenaceum does not, although some isolates of $F$. acuminatum were slow to form chlamydospores in culture. Uncertainty about some " $F$. avenaceum" cultures remained due to their intermediate macroconidia shape, grading between acuminatum and avenaceum, and "failure" to produce chlamydospores. As a result, although ambiguous isolates were included in pathogenicity tests, our primary Koch's postulates confirmation was based on results with isolates that keyed most clearly to species.

F. solani (Mart.) Sacc. also occurred frequently among the total isolates collected (approximately $3.6 \%$ ). This species was easy to recognize by its stout macroconidia (Fig. $2 \mathrm{~K}$ to $\mathrm{M}$ ) and spherical chlamydospores (Fig. 2K), which often occurred in pairs. Most cultures were cream colored and light violet in the center (not shown). They produced abundant microconidia (Fig. 2L), and sporodochia were hyaline to cream colored.

Although isolated only from location 1, two Cylindrocarpon-like species were isolated from bare-root trees and budwood from this nursery during the period 1998-2001 and during the recent outbreak in 2011. The isolates from 2011 produced microconidia whereas the isolates collected during the earlier outbreak did not (Fig. 3). Based on the absence of microconidia, presence of chlamydospores, mostly single-septate macroconidia ( 37 to 55 by 5 to $12 \mu \mathrm{m})$, and occurrence in a temperate climate, the latter
Cylindrocarpon sp. most closely matched descriptions for Cylindrocarpon obtusiusculum (Sacc.) U. Braun (teleomorph Neonectria ramulariae $(9,17)$. Structures resembling stromata formed in a radial pattern around the central inoculation point on every medium used (Fig. 3A, C, and D). The color and structure of these aggregations were reminiscent of Nectria-like perithecia. However, at various developmental stages, many of these were crushed and microscopically examined (Fig. 3E) in an effort to see possible internal reproductive structures (e.g., asci) but none were observed.

In the recent outbreak in 2011, a second set of isolates from diseased Prunus seedlings were similar in morphology to $C$. destructans, most closely resembling a member within the teleomorph I. radicicola species complex (15). Microconidia (5 to 11 by 2.5 to $5 \mu \mathrm{m}$ ), macroconidia ( 10 to 32 by 3 to $6.5 \mu \mathrm{m}, 1$ to 3 septa), and chlamydospores were produced on PDA. Koch's postulates confirmed this isolate to be pathogenic and capable of producing measurable stem cankers in nonstressed almond branches within 4 weeks (Supplementary Figure S1).

Other fungi of note isolated from nursery seedlings include potential phytopathogens and mycoparasites. These were partially characterized by morphological features and are also listed within Table 1.
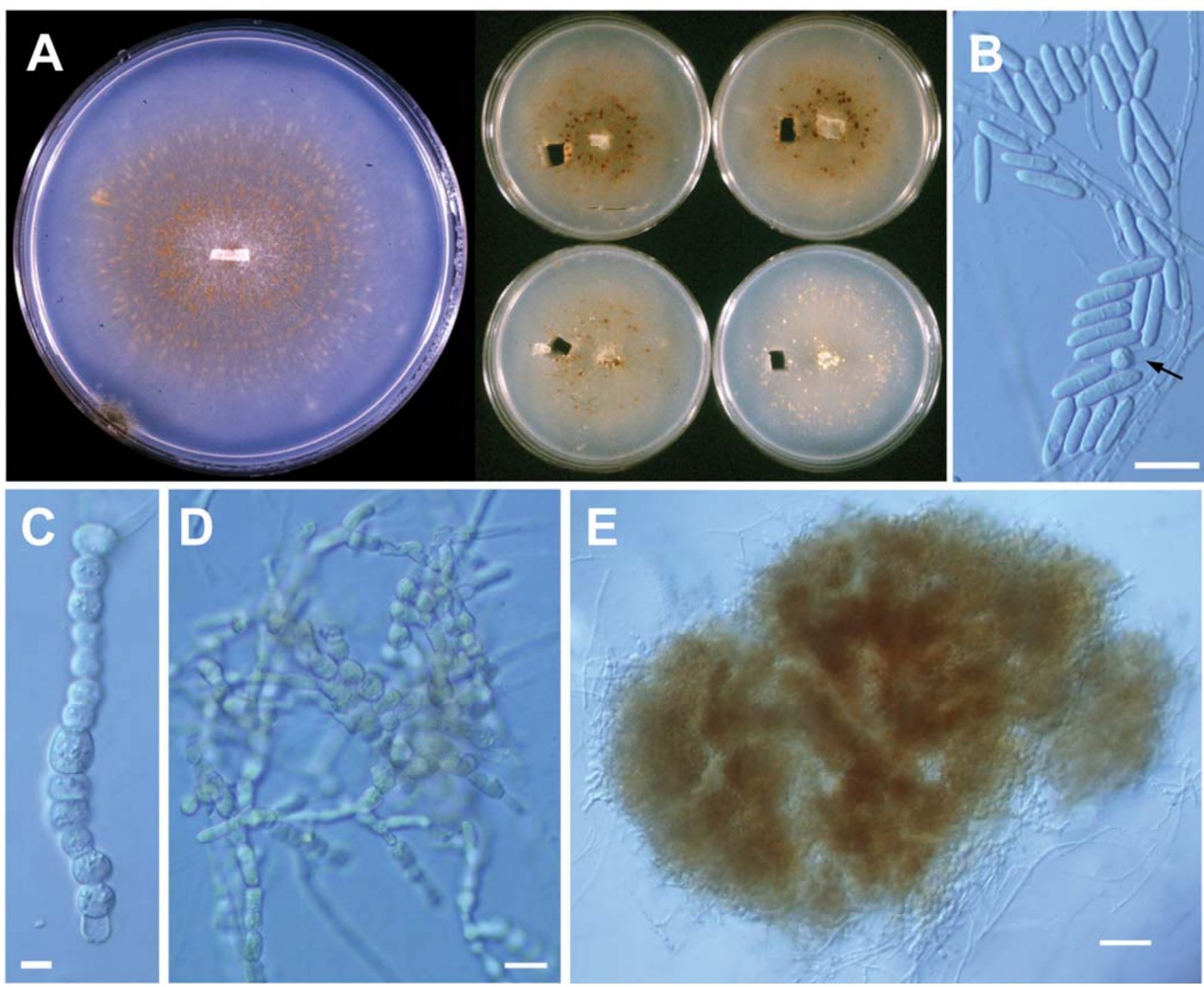

Fig. 3. Cylindrocarpon obtusiusculum isolated from almond trees and budwood from one nursery. A, Characteristic red-orange to reddish brown structures formed in the agar in a radial pattern in cultures. C-E, These structures appeared to develop from coalesced chains of chlamydospores. Although appearing in color to be Nectria-like stromata, no spores were formed specifically on or within these structures, suggesting these may be sclerotia. Conidia (0 to 3 septate) were formed on simple and branched monophialidic conidiophores and B, sometimes formed chlamydospores (arrow). All isolates of this species were obtained from almond trees at location 1. Bars $=50 \mu \mathrm{m}(B$ and D), $20 \mu \mathrm{m}(\mathrm{C})$, and $200 \mu \mathrm{m}(\mathrm{E}$. 
Disease assays. Only isolates of $F$. acuminatum, F. avenaceum, $F$. solani, and the Cylindrocarpon spp. from all locations fulfilled the criteria to meet Koch's postulates using the final pathogenicity test under drying conditions (Fig. 4). In a preliminary experiment, composite data from almond branch segments inoculated with several Fusarium and Cylindrocarpon isolates revealed that lesion areas (canker length by width) were greater in dry-incubated branch segments than in wet-incubated branch segments (Fig. 4C). The canker lesion data presented in Figure 4 did not satisfy the analysis of variance criterion for normality and, thus, were analyzed by the Wilcoxon rank sums test $\left(\chi^{2}, 5.48, P=0.019\right.$; JMP software, version 9.0; SAS Institute). Several other fungi caused lesions, fulfilling the first three postulates, but failed to be reisolated from inoculated tissues. Instead, F. acuminatum and $F$. avenaceum were often "reisolated" from these test stem segments, suggesting that they were likely present as endophytic latent infections and activated by the conditions of the pathogenicity tests. Several of the $F$. solani field isolates were capable of causing lesions in turgid almond stem segments in addition to desiccationpredisposed stems (data not shown). M. fructicola proved to be a consistently aggressive positive control, whereas $M$. laxa was inconsistent in this regard.

DNA sequence analyses. Isolates morphologically identified as $F$. acuminatum and $F$. avenaceum were confirmed by EF1- $\alpha$ sequence information (GenBank accession numbers JN811692 and JN811693, respectively). Approximately 710 bp of the EF1- $\alpha$ were amplified. Based on BLAST results, Fusarium spp. sequences had maximum similarity and matched the identity of $F$. acuminatum and $F$. avenaceum. The isolates morphologically identified as $C$. obtusiusculum during the initial outbreak in 1997-98 were confirmed by ITS sequence identity for this species (syn. C. magnusianum; JF735314). The sequence from the Cylindrocarpon sp. isolated in 2011 matched $\beta$-TUB sequences from the teleomorphic stage I. robusta $(15,16$; JQ309826).

Relative bark turgidity and susceptibility to $F$. acuminatum. A drying period of $\geq 4$ days at ambient humidity (34 to $42 \%$ relative humidity at $15^{\circ} \mathrm{C}$ ) appeared to be necessary to initiate lesions characteristic of those observed in naturally infected trees (Fig. $5 \mathrm{~A})$. In contrast, restricted bullseye lesions were formed with drying periods of $\leq 3$ days (Fig. 5A, inset), which could represent a partial defense of turgid stem segments mounted against the inoculated fungus. Relative bark turgidity of almond stem segments dropped from 88 to $84 \%$ over the 14-day incubation period (Fig. 5B). Loss of bark turgidity correlated with increased susceptibility of almond stem segments as measured by lesion lengths to $F$. acuminatum (Fig. 5C). The most extensive lesions (>30 mm) occurred after relative bark turgidity dropped below a threshold of $86 \%$, with susceptibility as measured by lesion length increasing exponentially as bark turgidity dropped below this point (Fig. 5B and C). Data presented are from one experiment, and the experiment was repeated with similar results.

Latent infections and sources of primary inoculum. Healthy almond trees (Padre, 'Peerless', 'Price', and 'Butte'), almond scion budwood ('Sonora' and Padre), and cover-crop wheat plants sampled from location 1 all possessed asymptomatic infections of $F$. acuminatum, $F$. avenaceum, and $C$. obtusiusculum as determined by activation through freezing, cold storage $\left(4^{\circ} \mathrm{C}\right)$, or desiccation. $F$. acuminatum and $F$. avenaceum frequently were isolated from healthy almond (Padre) tree stems, asymptomatic infections of which were detected readily by freeze activation (Fig. 6B) and, to a lesser extent, by desiccation activation (Fig. 6A). Green budwood sticks became lesioned while cold stored and wrapped in moist newspaper, a common nursery practice. Although $F$. acuminatum and $F$. avenaceum were isolated from budwood lesions, Botrytis cinerea, $C$. obtusiusculum, and $F$. solani were more frequently encountered. Freeze activation of unlesioned budwood promoted heavy sporulation of several saprobic fungi, preventing identification and isolation of Fusarium spp. F. acuminatum and F. avenaceum were isolated only once each from senescing wheat plants in April. F. solani and F. equiseti were isolated more frequently. No
Fusarium spp. were isolated from peach rootstock saplings sampled from a nursery bed prior to grafting or from wheat seed used to plant cover crops. Seedlings from stratified almond ('Mission') seed planted into soil artificially infested with $F$. acuminatum and C. obtusiusculum failed to become infected.

\section{Discussion}

Of the numerous fungi isolated from diseased trees, we found that only $F$. acuminatum, F. avenaceum, F. solani, and the two Cylindrocarpon spp. were capable of reproducing disease lesions on almond tree segments and met the criteria to fulfill Koch's postulates through post-infection recovery. Fusarium spp. have been reported sporadically as causal agents of many canker and wilt diseases of trees (7). Fusarium spp. (42,57) and C. destructans (Zinssm.) Scholten (52) have been reported infrequently from Prunus spp., specifically.

F. acuminatum is a cosmopolitan fungus (teleomorph Gibberella acuminata Wollenw.) that is commonly found in soils and on numerous plants in temperate climates. It is thought to subsist saprobically but can act as a weak pathogen resulting in subtle symp-
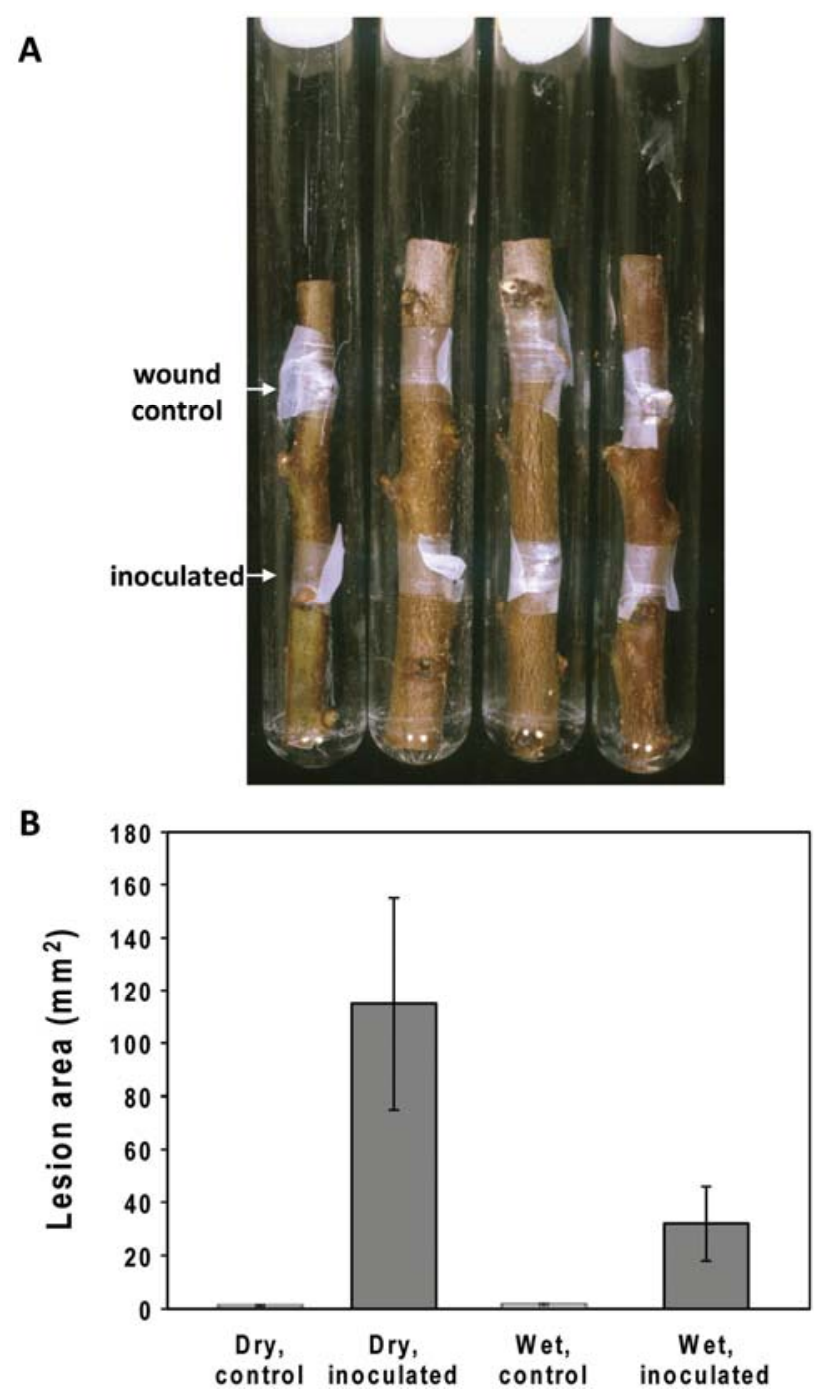

Fig. 4. Pathogenicity tests performed at dry ambient relative humidity resulted in larger lesions from Fusarium avenaceum, F. acuminatum, F. solani, and Cylindrocarpon obtusiusculum. A, Almond stem segments showing points of inoculation and control (noninoculated) treatment. B, Significantly longer lesions resulted when branches were incubated at ambient humidity (Dry), compared with lesions that formed when tests were performed at $100 \%$ relative humidity (Wet). Combined lesion lengths \pm S.E.M.; averaged for nine isolates representing the three Fusarium spp. and three isolates of $C$. obtusiusculum. Canker lengths between Dry and Wet formats were significantly different by Wilcoxon rank sums test $\left(\chi^{2}, 5.48, P=\right.$ 0.019). 


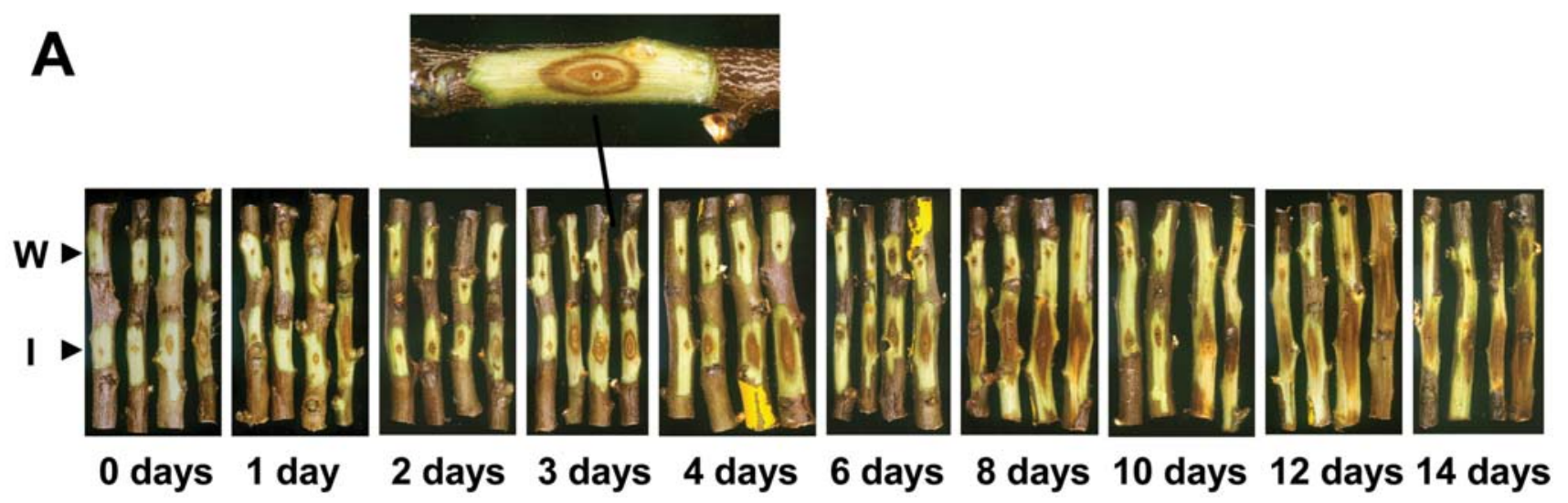

B

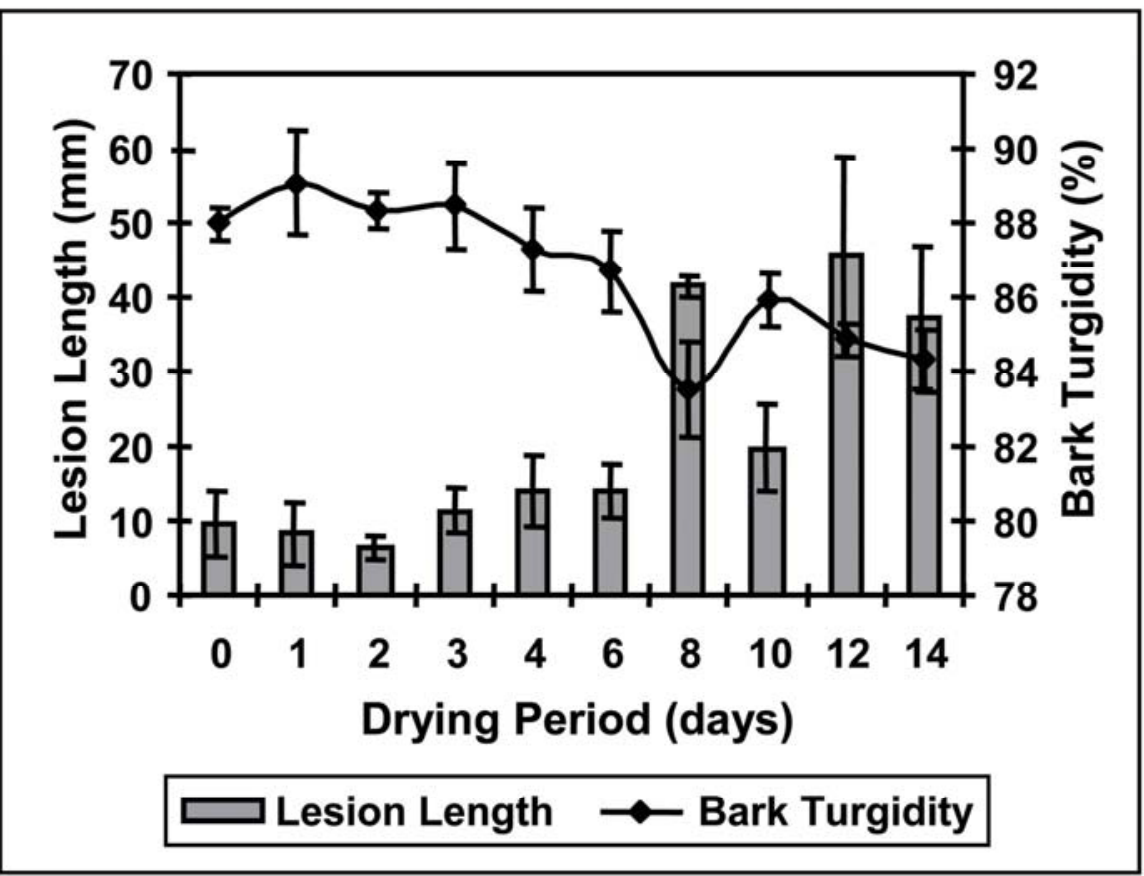

C

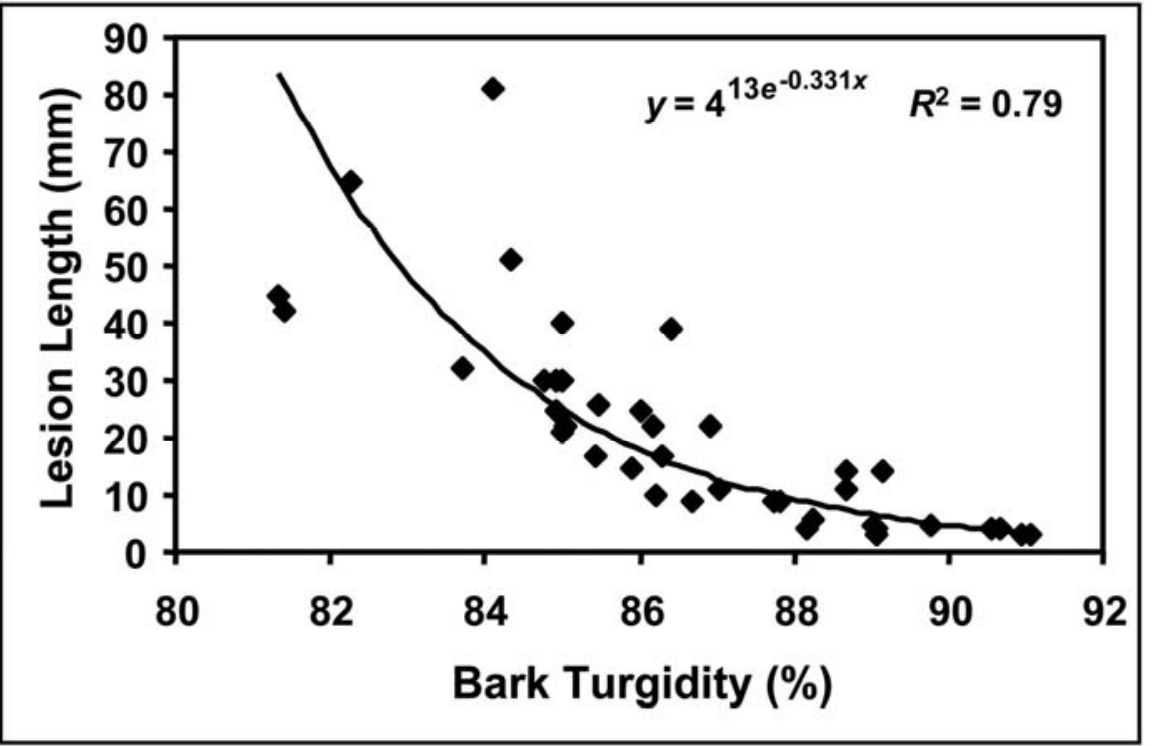

Fig. 5. Relationship of bark turgidity and susceptibility of dormant almond tree segments to Fusarium acuminatum. Inoculated and noninoculated dormant almond tree segments were incubated at $15^{\circ} \mathrm{C}$ at ambient humidity for 14 days. $\mathbf{A}$ and $\mathbf{B}$, Stem segments were allowed to dry for the number of days indicated, after which sterile distilled water was added to the tubes to stop desiccation. Incubation at $15^{\circ} \mathrm{C}$ continued until the remainder of the 14 days had passed. Resulting lesions on stems inoculated with $F$. acuminatum are shown in A ("W" = wound control and "I" = inoculated) and graphed in B. Striking "bullseye" lesions (close-up inset, A) occurred in stem segments permitted to dry for 0 to 3 days. B, Average lesion lengths and bark turgidities \pm S.D. at each time point. C, Correlation $\left(R^{2}=0.79\right)$ between tree susceptibility to $F$. acuminatum as measured by lesion length and bark turgidity. 
toms on hosts such as stunting and reduced yields (26). On hosts predisposed by stress such as freezing (22) or when it is combined with other pathogens (45), symptoms can be severe. F. acuminatum can also be a serious pathogen of various annual crops $(34,53)$ and of tree seedlings in forest nurseries $(28,43)$.

$F$. avenaceum is a cosmopolitan fungus occurring in most soils of temperate climates. Numerous subspecies and varieties of $F$. avenaceum have been named (40), and molecular analyses support the elevation of some subspecies to species rank (21). F. avenaceum is considered a soil-inhabiting saprobe that can act as a pathogen causing numerous diseases, including seedling blights and wilts of cereals, grasses, and legumes, and can be transmitted on host seed, soils, and plant debris. In perennial hosts, F. avenaceum has caused lesions on stone fruit (29) and a crown and stem rot of the ornamental lisianthus (39). Also, seedborne $F$. avenaceum causes damping off and seedling blights in forest nurseries $(1,30)$. The almond trees from which $F$. avenaceum and $F$. acuminatum were isolated in this study were grown in nursery fields previously cover-cropped under wheat; thus, these isolates could also be pathogenic on cereals. F. avenaceum and F. acuminatum
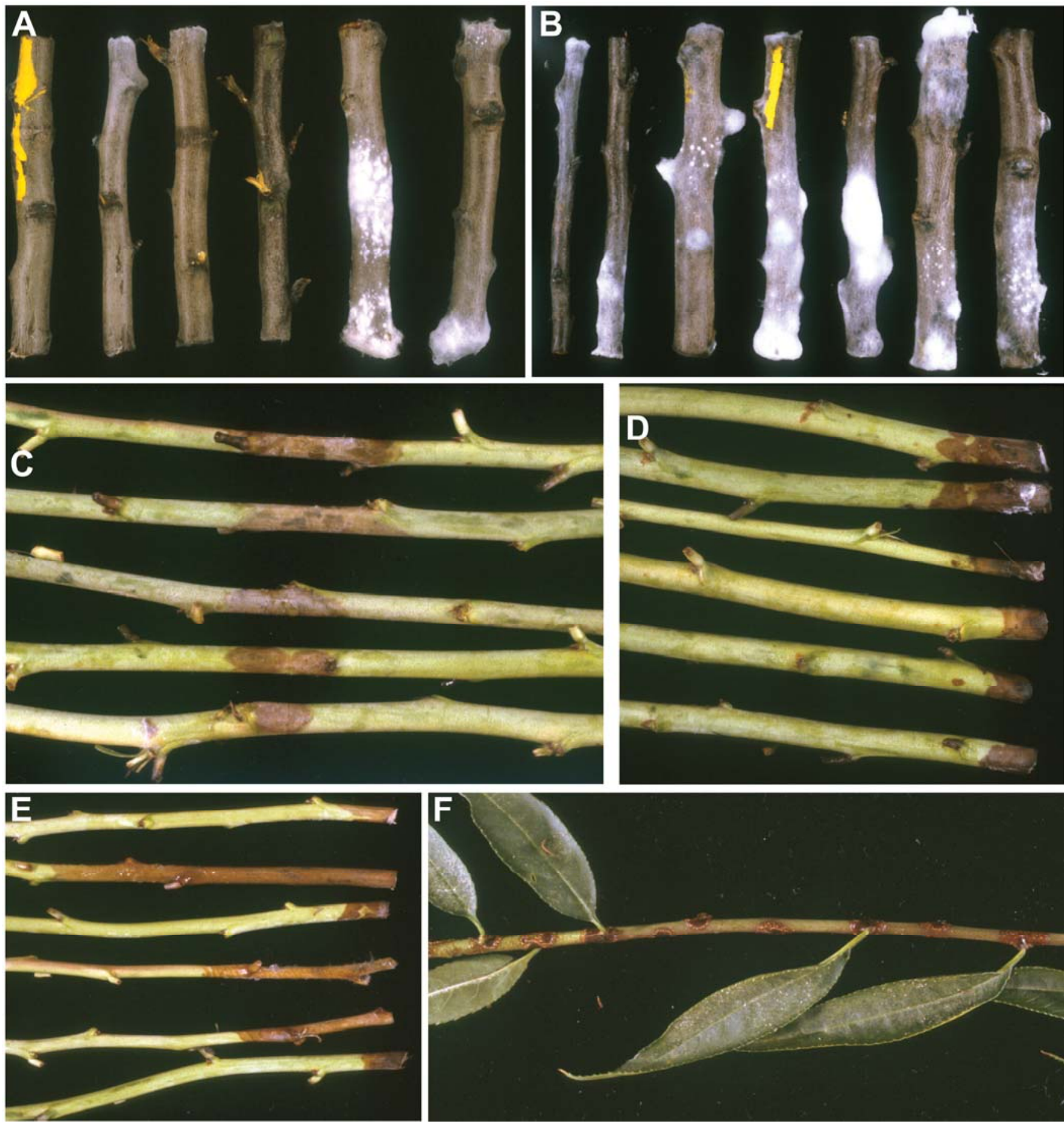

Fig. 6. Activation of endophytic asymptomatic infections and potential sources of primary inocula. Asymptomatic infections harbored by surface-sterilized, healthy-appearing almond ('Padre') stem segments were activated after A, 32 days of desiccation at ambient humidity at $15^{\circ} \mathrm{C}$ and B, after an overnight freeze at $-20^{\circ} \mathrm{C}$ followed by 32 days at $100 \%$ relative humidity and $22^{\circ} \mathrm{C}$ (room temperature) to promote sporulation. Fusarium acuminatum and $F$. avenaceum were frequently recovered from activated infections of stem segments. Asymptomatic infections of almond scion budwood of $\mathbf{C}$ and $\mathbf{D}$, 'Sonora' and $\mathbf{E}$, Padre were activated after cold storage $\left(4\right.$ to $\left.10^{\circ} \mathrm{C}\right)$ for 30 days. Fungi recovered from budwood infections included Botrytis cinerea, a Cylindrocarpon sp., and F. acuminatum. F, Peach 'Nemaguard' rootstock seedlings developed nodal lesions with raised margins after 60 days in the greenhouse; however, only saprobic fungi were isolated. All specimens were from location 1. 
can resemble one another to such an extent that it can be difficult to distinguish them $(36,44,50)$. Some isolates failed to produce sporodochia on CLA or SNA, on which taxonomically typical macroconidia should have formed. However, polyphasic approaches combining morphological and DNA sequence information have provided a means to better discriminate $F$. acuminatum and $F$. avenaceum and were used in our study to support our taxonomic characterization $(36,44,48)$.

F. solani $($ teleomorph $=$ Nectria haematococca Berk. \& Broome) likely inhabits every soil type on earth and opportunistically parasitizes numerous susceptible hosts when present, frequently infecting through wounds or lesions caused by other fungi (10). In forest tree nurseries, $F$. solani frequently causes seed deterioration, damping off, cankers, and root rot of both conifers and hardwoods (7). Although numerous varieties and formae speciales of $F$. solani have been named (40), no isolates in this study were identified to forma speciales or variety level.

Booth's revision of the genus Cylindrocarpon divided it into four groups, with taxonomic separation largely based on the presence or absence of chlamydospores and microconidia and the shape, size and septation of macroconidia (9). Since that classic revision, the taxonomy of Cylindrocarpon and related genera with similar anamorphs has been further refined to incorporate species discoveries and delimitation within new teleomorphic stages based on contemporary molecular phylogeny data (17). Generally, species lacking chlamydospores are saprobes or weak pathogens of the aerial parts of woody plants and sometimes cause cankers or decline of weakened hosts (13). Species possessing chlamydospores are soil or rhizosphere inhabitants and also can be active plant pathogens. The Cylindrocarpon sp. isolated during the period 1998 to 2001 of this study combines both traits, by possessing chlamydospores and acting as a weak pathogen of the stems of almond. The conspicuous aggregations we observed with our isolates (Fig. 3) appeared to be aggregations of chlamydospores and resembled sclerotia. Interisolate pairings, if heterothallic, failed to result in reproductive structure formation. These isolates most closely resembled descriptions for C. obtusiusculum (=C. magnusianum), teleomorph Neonectria ramulariae $(11,20)$, and DNA sequence data affirmed this classification. However, earlier descriptions do not mention these conspicuous aggregations.

In the most recent outbreak, I. robusta was found in several diseased specimens and confirmed to be pathogenic on almond stems, and shares these same characteristics. I. robusta is a recently described species that is a component of the grapevine black foot disease complex (16). To our knowledge, I. robusta has not been reported previously as pathogenic on cold-stored Prunus seedlings as in the present study, although it has been documented to occur on $P$. cerasus in Canada (15).

Numerous plant diseases are caused by Cylindrocarpon spp., mostly on woody perennial hosts. $C$. destructans is a persistent rhizosphere inhabitant of forest trees (2) and can cause severe root rots in forest nurseries in combination with other fungi and on trees predisposed by stress (54). Also, several Cylindrocarpon spp. synergistically interact with other fungi, nematodes, and predisposing abiotic factors in disease complexes, such as replant diseases of apple (12) and Prunus spp. (4). C. destructans has been implicated as the cause of root and collar rots and a cold storage rot of Prunus spp. in Canada (52). A Canadian isolate of $C$. destructans from that study, however, failed to reproduce disease symptoms on almond stems under the experimental conditions of our study.

Predisposition of plants to disease by desiccation and drought stress has been described numerous times $(11,49,50)$, and is prominent in diseases caused by many Fusarium spp. (18). Many canker diseases of woody plants are especially exacerbated by moderate desiccation of host tissues $(6,19,23,38)$. The seminal work of Bier (5), Schoeneweiss (50), and Boddy (8) established desiccation stress as a major factor predisposing woody hosts to weak facultative fungi, which often reside endophytically and saprobically in the bark of their potential hosts. The mechanisms causing the activation of latent pathogens or cohabitant fungi are poorly under- stood, especially when they occur in dormant trees. The occurrence, causes, and control of "molds" on stored dormant trees have been reported occasionally (Supplementary Table S1), with Fusarium spp. frequently isolated from such trees. However, the species of Fusarium causing the canker disease in our study have not been reported in the literature on cold-stored seedlings.

In preliminary pathogenicity tests, no isolates were able to penetrate intact bark within the incubation period (52 days). Although penetration through lenticels or other natural openings is feasible, the pathogenic Fusarium and Cylindrocarpon spp. from our isolations were likely endophytically associated with trees as latent or asymptomatic infections. Localization of disease lesions around or above graft unions implies that these fungi may have gained access to trees during grafting. In a German study, sterilizing grafting knives between trees reduced mortality of bench-grafted maple trees caused by Fusarium spp. (48). However, causal species of Cylindrocarpon and Fusarium were present in the budwood of the location 1 nursery (Fig. 6C-E), implicating propagative materials as a potential source of primary inoculum. Localized nodal lesions on scions (Fig. 6G) may indicate that spores spread by misted water in cold storage facilities became trapped at buds. Alternatively, nodal tissues were more stress sensitive and became predisposed to endophytic inocula present in the scion, before internodal tissues.

The causal fungi are known to be soilborne $(13,56)$, and many nursery fields are rotated through cereal crops, primarily wheat, on which $F$. avenaceum is known to be a common root endophyte (20). Thus, significant inoculum could be present in nursery soils. Even though rootstocks in direct contact with potentially infested soils were mostly lesion free, lack of symptoms could indicate that rootstocks were tolerant of systemic infections. Additionally, in the past, nurseries fumigated seedbeds with methyl bromide prior to planting trees, which likely eliminated most inoculum. As fumigation has become restricted, soil inoculum loads may increase to favor infection of rootstocks or infection through graft wounds.

After lifting, washing, and grading, trees are sometimes heeled in sawdust bedding to maintain moisture around the desiccationsensitive roots, then either kept outside during the winter or placed in bins and put into cold storage. Sawdust is usually purchased from sawmills and is derived primarily from conifer trees. However, the nursery at one of the locations sampled for this study mixed conifer-based sawdust with mulched almond trees. Dilution plating of this sawdust bedding resulted in numerous pathogenic Fusarium isolates (Table 1). Trees predisposed during harvesting operations were likely exposed to high inoculum loads when packed into this conifer-almond sawdust. Pathogenic Fusarium isolates were not recovered from purely conifer-based sawdust (data not shown). Fusaria implicated in this study also can be seedborne (3). However, none of the causal fungi were isolated from peach rootstock seed tested.

The El Niño-La Niña weather patterns of 1997-99 and the abundant rain in northern California during 2010-11 likely contributed indirectly to the predisposition of trees to this disease. Nurseries reported that, during the El Niño years of 1997 and 1998, earlierthan-normal rains in the fall prevented timely lifting and grading of dormant trees from nursery beds to cold storage. When nurseries were finally able to reenter muddy fields to lift trees, the normal orderly schedule of lifting, cleaning, and grading trees prior to placing them into cold storage was hurried and disorganized. Uprooted trees were allowed to sit outside on pallets for extended periods ( 7 to 14 days by some estimates) while grading caught up. Trees likely became predisposed to latent infections by desiccation during this period. In this study, it took 8 to 10 days at ambient humidity and $15^{\circ} \mathrm{C}$ to drop bark turgidity low enough to predispose almond stem segments to $F$. acuminatum. Predisposed trees were then placed into cold storage in December and sprinkled with water daily. Symptomatic trees began to be noticed in February.

In the La Niña years of 1998 to 1999, a series of hard frosts with temperatures as low as $-5.5^{\circ} \mathrm{C}$ in late December likely injured trees remaining in the field. Additionally, the refrigerated warehouses in which trees were placed regularly dropped below $0^{\circ} \mathrm{C}$, as indicated 
by observations of ice on the surface of storage bins. These freeze events may have predisposed the trees to Fusarium spp. (27). We also found that the $F$. acuminatum and $F$. avenaceum isolates in our study were ice-nucleation active (36), a finding that has been reported previously (46). The contribution of ice-nucleating activity of these species to canker development is unresolved and under further investigation.

Our results suggest that cold storage canker of Rosaceous trees (a proposed disease name) begins with latent infections by endophytic facultative species of Fusarium and Cylindrocarpon that are introduced from contaminated budwood during grafting or from soilborne inoculum attacking rootstocks or becoming windborne in the field to accumulate on tree surfaces. Abiotic stresses incurred by dormant trees in the field and during lifting, grading, storage, and shipping may activate latent infections so that infection courts are established. Predisposing stresses can be minimized through lifting trees from the fields prior to hard frosts, maintaining storage temperatures between 0 and $4{ }^{\circ} \mathrm{C}$, keeping trees well hydrated without excessive free water, and transplanting trees quickly to the growers' fields after removing from cold storage. If cumulative stresses sufficiently predispose trees, latent infections will activate and necrotize surrounding bark, cambia, and sapwood. This pathogenic phase may not be apparent after removal from cold storage, resulting in diseased trees collapsing after transplantation to the grower's field.

California nurseries are shifting toward containerized systems for propagation of fruit and nut trees, which should obviate many of the issues associated with field propagation and the predisposing stresses associated with cold storage of bare-root seedlings. Nonetheless, refrigerated storage continues to be a significant practice with several major nurseries. Management strategies for cold storage canker of Rosaceous trees should focus on cultural practices that minimize predisposing stress. The extent of infection of propagation materials should be assessed and eradication of pathogenic fungi from these materials could be worthwhile. Review and modification of these practices by the fruit and nut tree nurseries in California has occurred since reporting our initial results (36). However, as the recent 2011 outbreak attests, continued vigilance will be important to reduce disease risk and economic losses. The increasing importance of Fusarium spp. and their allies in many plant diseases is well recognized (21). Our results further suggest that careful assessment of ubiquitous Fusarium and Cylindrocarpon spp. that includes Koch's postulates performed on nonstressed and moderately stressed plants should be made to evaluate each species' potential to cause disease in a given host.

\section{Acknowledgments}

Research was supported by grants from the California Fruit Tree, Nut Tree, and Grapevine Improvement Advisory Board to R. M. Bostock. We thank P. Verdegaal, UC Cooperative Extension, San Joaquin County, for obtaining many of the disease samples used in this study; and J. A. Traquair, Agriculture Canada, for the gift of a $C$. destructans isolate.

\section{Literature Cited}

1. Asiegbu, F. O., Johansson, M., and Stenlid, J. 1999. Reactions of Pinus sylvestris (Scots pine) root tissues to the presence of mutualistic, saprotrophic and necrotrophic micro-organisms. J. Phytopathol. 147:257-264.

2. Axelrood, P. E., Chapman, W. K., Seifert, K. A., Trotter, D. B., and Shrimpton, G. 1998. Cylindrocarpon and Fusarium root colonization of Douglas-fir seedlings from British Columbia reforestation sites. Can. J. For. Res. 28:1198-1206

3. Axelrood, P. E., Neumann, M., Trotter, D., Radley, R., Shrimpton, G., and Dennis, J. 1995. Seedborne Fusarium on Douglas-fir: pathogenicity and seed stratification method to decrease Fusarium contamination. New For. 9:35-51.

4. Bhat, R. G., Schmidt, L. S., and Browne, G. T. 2011. Quantification of Cylindrocarpon sp. in roots of almond and peach trees from orchards affected by Prunus replant disease. (Abstr.) Phytopathology 101:S15.

5. Bier, J. E. 1964. The relation of some bark factors to canker susceptibility. Phytopathology 54:250-253.

6. Blodgett, J. T., Kruger, E. L., and Stanosz, G. R. 1998. Effects of moderate water stress on disease development by Sphaeropsis sapinea on red pine. Phytopathology 87:422-428.

7. Bloomberg, W. J. 1981. Diseases caused by Fusarium in forest nurseries.
Pages 178-187 in: Fusarium: Diseases, Biology, and Taxonomy. P. E. Nelson, T. A. Tousson and R. J. Cook, eds. Pennsylvania State University Press, University Park.

8. Boddy, L., and Griffith, G. S. 1989. Role of endophytes and latent invasion in the development of decay communities in sapwood of angiospermous trees. Sydowia 41:41-73.

9. Booth, C. 1966. The genus Cylindrocarpon. Mycol. Pap. 104:56.

10. Booth, C. 1971. The genus Fusarium. Commonwealth Agricultural Bureaux for the Commonwealth Mycological Institute, Farnham Royal, UK.

11. Boyer, J. S. 1995. Biochemical and biophysical aspects of water deficits and the predisposition to disease. Annu. Rev. Phytopathol. 33:251-274.

12. Braun, P. G. 1995. Effects of Cylindrocarpon and Pythium species on apple seedlings and potential role in apple replant disease. Can. J. Plant Pathol. 17:336-341.

13. Brayford, D. 1992. Cylindrocarpon. Pages 103-106 in: Methods for Research on Soilborne Phytopathogenic Fungi. L. L. Singleton, J. D. Mihail, and C. M. Rush, eds. American Phytopathological Society, St. Paul, MN.

14. Burgess, L. W., Summerell, B. A., Bullock, S., Gott, K. P., and Backhouse, D. 1994. Laboratory Manual for Fusarium Research. Fusarium Research Laboratory, Department of Crop Sciences, University of Sydney and Royal Botanic Gardens, Sydney.

15. Cabral, A., Groenewald, J. Z., Rego, C., Oliveira, H., and Crous, P. W. 2012. Cylindrocarpon root rot: multi-gene analysis reveals novel species within the Ilyonectria radicicola species complex. Mycol. Prog. 11:655-688.

16. Cabral, A., Rego, C., Nascimento, T., Oliveira, H., Groenewald, J. Z., and Crous, P. W. 2012. Multi-gene analysis and morphology reveal novel Ilyonectria species associated with black foot disease of grapevines. Fungal Biol. 116:62-80.

17. Chaverri, P., Salgado, C., Hirooka, Y., Rossman, A. Y., and Samuels, G. J. 2011. Delimitation of Neonectria and Cylindrocarpon (Nectriacea, Hypocreales, Ascomycota) and related genera with Cylindrocarpon-like anamorphs. Stud. Mycol. 68:57-78.

18. Cook, R. J. 1981. Water relations in the biology of Fusarium. Pages 236244 in: Fusarium: Diseases, Biology, and Taxonomy. P. E. Nelson, T. A. Tousson, and R. J. Cook, eds. Pennsylvania State University Press, University Park.

19. Crist, C. R., and Schoeneweiss, D. F. 1975. The influence of controlled stresses on susceptibility of European white birch stems to attack by Botryosphaeria dothidea. Phytopathology 65:369-373.

20. Crous, P. W., Petrini, O., Marais, G. F., Pretorius, Z. A., and Rehder, F. 1995. Occurrence of fungal endophytes in cultivars of Triticum aestivum in South Africa. Mycoscience 36:105-111.

21. Desjardins, A. E. 2003. Gibberella from A (venaceae) to $Z$ (eae). Annu. Rev. Phytopathol. 41:177-198.

22. Fernandez, J. A., Wofford, D. S., and Horton, J. L. 1985. Interactive effects of freezing and common root rot fungi on winter wheat. Phytopathology 75:845-847.

23. Gao, S., and Shain, L. 1995. Effects of water stress on chestnut blight. Can. J. For. Res. 25:1030-1035.

24. Geiser, D. M., Jimenez-Gasco, M. D., Kang, S. C., Makalowska, I., Veeraraghavan, N., Ward, T. J., Zhang, N., Kuldau, G. A., and O'Donnell, K. 2004. FUSARIUM-ID v. 1.0: a DNA sequence database for identifying Fusarium. Eur. J. Plant Pathol. 110:473-479.

25. Gerlach, W., and Nirenberg, H. 1982. The Genus Fusarium : A Pictorial Atlas. Kommissionsverlag P. Parey, Berlin.

26. Gonzalez, M. S., and Trevathan, L. E. 2000. Identity and pathogenicity of fungi associated with root and crown rot of soft red winter wheat grown on the Upper Coastal Plain Land Resource Area of Mississippi. J. Phytopathol. 148:77-85.

27. Gross, D. C., Proebsting, E. L., Jr., and Maccrindle-Zimmerman, H. 1988 Development, distribution, and characteristics of intrinsic, nonbacterial ice nuclei in Prunus wood. Plant Physiol. 88:915-922.

28. Hansen, E. M., and Hamm, P. B. 1988. Canker diseases of Douglas-fir seedlings in Oregon and Washington bareroot nurseries. Can. J. For. Res. 18:1053-1058

29. Hartill, W. F. T., and Broadhurst, P. G. 1989. Fusarium avenaceum as a pathogen of stonefruit in New Zealand. N.Z. J. Crop Hortic. Sci. 17:293-295.

30. James, R. L., Dumroese, R. K., and Wenny, D. L. 1988. Fusarium diseases of containerized conifer seedlings in northern Rocky Mountain nurseries: infection, symptom production, and pathogenicity of associated Fusaria. (Abstr.) Phytopathology 78:1533.

31. Kannwischer, M. E., and Mitchell, D. J. 1978. The influence of a fungicide on the epidemiology of black shank of tobacco. Phytopathology 68:17601765

32. King, E. O., Ward, M. K., and Raney, D. E. 1954. Two simple media for the demonstration of pyocyanin and fluorescin. J. Lab. Clin. Med. 44:301-307.

33. Klotz, L. V., Nelson, P. E., and Toussoun, T. A. 1988. A medium for enhancement of chlamydospore formation in Fusarium spp. Mycologia 80:108-109.

34. Lamprecht, S. C., Knox-Davies, P. S., and Marasas, W. F. O. 1984. Fusarium spp. associated with diseased root and crown tissue of annual Medicago spp. Phytophylactica 16:195-200.

35. Liddell, C. M. 1985. The comparative pathogenicity of Fusarium graminearum group 1, Fusarium culmorum and Fusarium crookwellense as crown, 
foot and root rot pathogens of wheat. Australas. Plant Pathol. 14:29-32

36. Marek, S. M., and Bostock, R. M. 2000. Etiology of cold storage canker of fruit and nut trees in California. (Abstr.) Phytopathology 90:S49.

37. Michailides, T. J., Morgan, D. P., and Felts, D. 2000. Detection and significance of symptomless latent infection of Monilinia fructicola in California stone fruits. (Abstr.) Phytopathology 90:S53.

38. Mullen, J. M., Gilliam, C. H., and Hagan, A. K. 1991. Canker of dogwood caused by Lasiodiplodia theobromae, a disease influenced by drought stress or cultivar selection. Plant Dis. 75:886-889.

39. Nalim, F. A., Elmer, W. H., McGovern, R. J., and Geiser, D. M. 2009. Multilocus phylogenetic diversity of Fusarium avenaceum pathogenic on Lisianthus. Phytopathology 99:462-468.

40. Neish, G., Nirenberg, H. I., Samuels, G. J., Seifert, K. A., and Thrane, U. 1998. Database of Fusarium Names. ISPP/ICTF Fusarium working group, CentraalBureau voor Schimmelcultures (CBS), Utrecht, The Netherlands.

41. Nelson, P. E., Toussoun, T. A., and Marasas, W. F. O. 1983. Fusarium Species: An Illustrated Manual for Identification. Pennsylvania State University Press, University Park.

42. Nyczepir, A. P., and Pusey, P. L. 1986. Association of Criconemella xenoplax and Fusarium spp. with root necrosis and growth of peach. J. Nematol. 18:217-220.

43. Ocamb, C. M., and Juzwik, J. 1995. Fusarium species associated with rhizosphere soil and diseased roots of eastern white pine seedlings and associated nursery soil. Can. J. Plant Pathol. 17:325-330.

44. O'Donnell, K., and Cigelnik, E. 1997. Two divergent intragenomic rDNA ITS2 types within a monophyletic lineage of the fungus Fusarium are nonorthologous. Mol. Phylogenet. Evol. 7:103-116.

45. Percich, J. A., and Johnson, D. R. 1990. A root rot complex of horseradish. Plant Dis. 74:391-393.

46. Pouleur, S., Richard, C., Martin, J. G., and Antoun, H. 1992. Ice nucleation activity in Fusarium acuminatum and Fusarium avenaceum. Appl. Environ.
Microbiol. 58:2960-2964.

47. Sambrook, J., and Russell, D. W. 2001. Molecular Cloning: A Laboratory Manual. Cold Spring Harbor Laboratory Press, Cold Spring Harbor, NY.

48. Sanftleben, H. 1985. Disinfection and other treatments of bench grafts. Page 161 in: Communications, Federal Biology Institute for Agriculture and Forestry, Berlin-Dahlem West German Federal Biological Institute for Agriculture and Forestry, Berlin-Dahlem.

49. Schoeneweiss, D. F. 1975. Predisposition, stress, and plant disease. Annu. Rev. Phytopathol. 13:193-211.

50. Schoeneweiss, D. F. 1986. water stress predisposition to disease: an overview. Pages 157-174 in: Water, Fungi and Plants. P. G. Ayres and L. Boddy, eds. Cambridge University Press, Cambridge.

51. Singleton, L. L., Mihail, J. D., and Rush, C. M. 1992. Methods for Research on Soilborne Phytopathogenic Fungi. American Phytopathological Society, St. Paul, MN.

52. Traquair, J. A., and White, G. P. 1992. Cylindrocarpon rot of fruit trees in cold storage. Can. J. Plant Pathol. 14:310-314.

53. Uddin, W., and Knous, T. R. 1991. Fusarium spp. associated with crown rot of alfalfa in Nevada. Plant Dis. 75:51-56.

54. Unestam, T., Beyer-Ericson, L., and Strand, M. 1989. Involvement of Cylindrocarpon destructans in root death of Pinus sylvestris seedlings: pathogenic behavior and predisposing factors. Scand. J. For. Res. 4:521-536.

55. White, T. J., Bruns, T., Lee, S., and Taylor, J. 1990. Amplification and direct sequencing of fungal ribosomal RNA genes for phylogenetics. Pages 315322 in: PCR Protocols. M. A. Innis, D. H. Gelfand, J. J. Sninski, and T. J. White, eds. Academic Press, San Diego, CA

56. Windels, C. E. 1992. Fusarium. Pages 115-128 in: Methods for Research on Soilborne Phytopathogenic Fungi. L. L. Singleton, J. D. Mihail, and C. M. Rush, eds. American Phytopathological Society, St. Paul, MN.

57. Young, G. Y. 1943. Root rots in storage of deciduous nursery stock and their control. Phytopathology 33:656-665. 